\title{
Hand hygiene multimodal strategy and the decrease on central line-associated bloodstream infection in a Brazilian neonatal intensive care unit
}

\author{
R Richtmann*, G Pereira, T Rodrigues, ACO Filhiolino, KM Gama, C Dealmeida Silva, L Dias \\ From 3rd International Conference on Prevention and Infection Control (ICPIC 2015) \\ Geneva, Switzerland. 16-19 June 2015
}

\section{Introduction}

Hand hygiene $(\mathrm{HH})$ is the most important strategy to reduce healthcare associated infection. Central line associated bloodstream infection (CLABSI) is the most frequent and severe infection in the Neonatal intensive care unit (NICU).

\section{Objectives}

In this work we describe the impact of World Health Organization (WHO) multimodal strategy implementation on the CLABSI incidence in the NICU.

\section{Methods}

The WHO multimodal strategy was recommended by Sao Paulo State government in 2011 to all hospitals as a part of the campaign "Save lives: clean your "hands". Our HH multi-professional team implemented several strategies as checking the infrastructure for $\mathrm{HH}$, education and training, videos, $\mathrm{HH}$ playful campaigns, games, creation of a $\mathrm{HH}$ mascot. All actions were followed by continuous feed backs of compliance to $\mathrm{HH}$ and infection rates to healthcare workers and were coordinated by the infection control committee and supported by the hospital leadership.

A prospective study during 2011 to 2014 in a maternity hospital with 63 NICU beds in Sao Paulo city/Brazil.

\section{Results}

The alcohol based product consumption for $\mathrm{HH}$ increased during this period from $33.8 \mathrm{ml}$ to $90.0 \mathrm{ml} /$ patient-day and , and the $\mathrm{HH}$ compliance increased from $63.0 \%$ to $84.0 \%$, on the opposite the CLABSI incidence in the NICU reduced from 6.2 CLABSI/1000 Central Line (CL)-day to 1.5 CLABSI/1000 CL-day.

Maternity Hospital Pro MatrePaulista, São Paulo, Brazil

\section{Conclusion}

The WHO multimodal strategy implementation wascrucialto guide the actions and systematization of the $\mathrm{HH}$ multiprofessional team. The commitment of a multiprofessional $\mathrm{HH}$ team was determinant to our outcome. We do have "saved lives" with all these actions and on 2014 both hospitals won the WHO Latin America HH excellence award as recognition of all our accomplishments.

\section{Disclosure of interest}

None declared.

Published: 16 June 2015

doi:10.1186/2047-2994-4-S1-P155

Cite this article as: Richtmann et al:: Hand hygiene multimodal strategy and the decrease on central line-associated bloodstream infection in a

Brazilian neonatal intensive care unit. Antimicrobial Resistance and Infection Control 2015 4(Suppl 1):P155.

Submit your next manuscript to BioMed Central and take full advantage of:

- Convenient online submission

- Thorough peer review

- No space constraints or color figure charges

- Immediate publication on acceptance

- Inclusion in PubMed, CAS, Scopus and Google Scholar

- Research which is freely available for redistribution

Submit your manuscript at www.biomedcentral.com/submit 